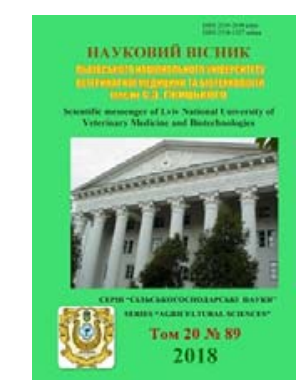

UDC 636.2.034.082.2

Науковий вісник Яьвівського націонадьного університету
ветеринарної медицини та біотехнологій імені С.3. Гжицького

\author{
Scientific Messenger of Lviv National University \\ of Veterinary Medicine and Biotechnologies
}

\title{
The genetic determination of the economically useful characteristics of the cows of ukrainian black-and-white dairy breed
}

\author{
A.L. Shulyar \\ Zhytomyr National Agroecological University, Zhytomyr, Ukraine
}

Article info

Received 03.09.2018 Received in revised form 01.10 .2018

Accepted 02.10.2018

Zhytomyr National Agroecological University, Koroliov Str., 39, Zhytomyr, 10002, Ukraine. Tel.: +38-096-173-40-27 E-mail:alina_shu@i.ua

\begin{abstract}
Shulyar, A.L. (2018). The genetic determination of the economically useful characteristics of the cows of ukrainian black-and-white dairy breed. Scientific Messenger of Lviv National University of Veterinary Medicine and Biotechnologies, 20(89), 35-40. doi: 10.32718/nvlvet8906
\end{abstract}

The economically useful characteristics of dairy cows depend on many genetic, physiological, technological and environmental factors. The modern cow population of Ukrainian dairy cows was formed by using the improved Holstein breed. The contribution of this breed into both the creation and the improvement of Ukrainian black-and-white dairy breed is reflected in its genealogic structure, as the prevailing part of the lines is of Holstein origin. That's why the estimation of animals of different lines and the male descendants of the bulls in service according to the main economically useful characteristics is one of the most topical matters concerning the improvement of the rate of genetic potential realization of the animals under peculiar conditions as well as of the formation of highly productive and profitable dairy herds. As it follows from mentioned above, the goal of our research was to determine the effects of the bulls in service and their belonging to the line on economically useful characteristics of the cows. The material for the research was the information concerning the breed and productive use of the cows of Ukrainian black-and-white dairy breed on the breeding plant of the private agrarian firm (PAF) "Yerchyky" of Zhytomyr oblast, as well as the results of private research. To make an analysis there was used the information about the cows which were lactating for the period of 7 years when the feeding and keeping conditions were similar ones. For the purpose of the research on the genetic determination of economically useful characteristics of the cows of Ukrainian black-and-white dairy breed, it has been made an analysis from among the groups of paternity and linear belonging. The comparison of group middle young cows' indices from different bulls in service and cows of various linear belonging has been made on the live mass, measurements and indices of body constitution, on milk productivity and morpho-functional characteristics of the udder as well as on their reproductive capacity. A considerable and highly reliable level of intergroup differentiation of cows of various linear belonging as well as of half-sisters by the bull has been determined on the economically useful characteristics. By means of single-factor variance analysis it has been determined that the paternity has a significant effect on the economically useful characteristics of cows that stipulates $0.71-21.92 \%$ of total phenotypic changeability of the characteristics being taken into account, whereas the belonging to the line was $0.54-12.70 \%$. The study of the effects of paternity and linear belonging of cows on the parameters of their life-long productivity will be the perspective of the further research.

Key words: parent, line, cow, half-sister, economically useful characteristics.

\section{Генетична детермінація господарськи корисних ознак корів української чорно-рябої молочної породи}

\author{
А.Л. Шуляр
}

Житомирський національний агроекологічний університет, Житомир, Украӥна

Господарськи корисні ознаки молочної худоби залежать від багатьох генетичних, фізіологічних, технологічних та середовищних факторів. Сучасне поголів'я украӥнських молочних порід формувалося з використанням поліпшувальної голитинської породи, внесок якої у створення і поліпшення украӥнської чорно-рябої молочної породи відображається у ї̈ генеалогічній структурі. Тому оцінка тварин різних ліній та нащадків бугаӥв-плідників за основними господарськи корисними ознаками є одним із актуальних питань галузі молочного скотарства. 3 огляду на зазначене, метою натої роботи було визначення впливу батьків корів та належності до лінії на господарськи корисні ознаки корів. Матеріалом досліджень слугувала інформація про племінне і продуктивне 
використання корів украӥнської чорно-рябої молочної породи племзаводу приватної агрофірми (ПАФ) “Ерчики” Житомирської області, а також результати власних досліджень. Для аналізу використано інформацію про корів, які лактували впродовж 7-ми років, коли умови годівлі і утримання були однаковими. Задля дослідження питання генетичної детермінації господарськи корисних ознак корів украӥнської чорно-рябої молочної породи проведено їх аналіз у розрізі груп походження за батьком та лінійної належності. Порівняння групових середніх дочок різних бугаїв та корів різної лінійної належності здійснено за жсиою масою, промірами, індексами будови тіла, за молочною продуктивністю, морфо-функціональними властивостями вимені та відтворювальною здатністю. Встановлено значний та високодостовірний у багатьох випадках рівень міжгрупової диференціації корів різноі лінійної належності, як і напівсестер за батьком, за досліджуваними господарськи корисними ознаками. Однофакторним дисперсійним аналізом встановлено, що суттєвіший вплив на господарськи корисні ознаки корів справляє походження за батьком, щчо зумовлює 0,71-21,92\% загальної фенотипової мінливості враховуваних ознак, тим часом як належність до лінії-0,54-12,70\%.

Ключові слова: батько, лінія, корова, напівсестра, господарськи корисна ознака.

\section{Вступ}

Господарськи корисні ознаки молочної худоби залежать від багатьох генетичних, фізіологічних, технологічних та середовищних факторів (Bazyshyna, 2017). Досвід учених і практиків багатьох країн світу свідчить про те, що підвищення генетичного потенціалу молочних порід худоби найшвидше досягається через виявлення та інтенсивне використання бугаївлідерів, без наявності яких в популяції подальший прогрес в селекції неможливий (Dmitriev et al., 1989; Rusnak and Shcherbatyy, 1999; Karacaören et al., 2006; Vandenplas et al., 2013).

Сучасне поголів'я української чорно-рябої молочної породи формувалося з використанням поліпшувальної голштинської породи, внесок якої у створення і покращення породи відображається у іiі генеалогічній структурі. Адже переважна частина ліній має голштинське походження (Shcherbatyi and Bodnar, 2015). Тому оцінка тварин різних ліній та нащадків бугаївплідників за основними господарськи корисними ознаками є одним із актуальних питань підвищення ступеня реалізації генетичного потенціалу тварин в конкретних умовах та формування високопродуктивних і рентабельних стад молочної худоби (Iliashenko and Polupan, 2009; Stavets'ka and Rudyk, 2011).

3 огляду на зазначене, метою нашої роботи було визначення впливу батьків та належності до ліній на господарськи корисні ознаки корів української чорнорябої молочної породи.

\section{Матеріал і методи досліджень}

Матеріалом досліджень слугувала інформація про племінне і продуктивне використання корів української чорно-рябої молочної породи племзаводу приватної агрофірми (ПАФ) “Ерчики” Житомирської області, а також результати власних досліджень. Для аналізу використано інформацію про корів, які лактували упродовж 7-ми років, коли умови годівлі й утримання були однаковими.

Екстер'єрно-конституційні особливості тварин різних порід вивчали за загальновизнаними методиками. Масо-метричний коефіцієнт (ММК) обчислювали за Д.Т. Вінничуком та ін. (1991), індекс ейрисомїлептосомії (IЕЛ) - за Н.М. Замятиным (1946.), індекс вираженості типу - за Й.3. Сірацьким (2001). Масу тіла корів досліджували на 2-3 місяці лактації шляхом зважування та за промірами з урахуванням вгодованості.
Надій від корів-первісток за 305 днів або вкорочену лактацію (не менше 240 днів) обчислювали за результатами щодекадного контролю упродовж перших 3-х місяців і щомісячного до закінчення лактації 3 одночасним визначенням у добових зразках молока вмісту жиру і білка. Морфо-функціональні властивості вимені досліджували за методикою Латвійської сільськогосподарської академії. Відтворювальну здатність корів вивчали за віком першого отелення, тривалістю сервіс-періоду, міжотельного періоду i за коефіцієнтом відтворної здатності за Н.З. Басовским (1991).

Статистичну обробку проводили за допомогою програмного пакету Microsoft Excel методами варіаційної статистики (Plohinskij, 1969; Merkur'eva, 1970). Результати середніх значень вважали статистично достовірними, якщо $\mathrm{P}<0,05$ (*) $^{\circ} \mathrm{P}<0,01$ (**), $\mathrm{P}<$ $0,001(* * *)$.

Силу впливу походження за батьком та лінійної належності обчислювали однофакторним дисперсійним аналізом як співвідношення факторіальної та загальної дисперсій (Plohinskij, 1970).

\section{Результати та їх обговорення}

Задля дослідження питання генетичної детермінації господарськи корисних ознак корів української чорно-рябої молочної породи проведено їх аналіз у розрізі груп походження за батьком та лінійної належності.

Порівняння групових середніх значень дочок різних бугаїв за масою тіла, промірами та індексами будови тіла показало значний рівень диференціації зазначених ознак у стаді племзаводу (табл. 1). За масою тіла різниця між кращою (батько - Астрономер 2160438) і гіршою (батько - Вірний 4975) групою складала 72,9 кг (P < 0,001), за висотою в холці 6,9 см $(\mathrm{P}<0,001)$, за косою довжиною тулуба $-4,2$ см $(\mathrm{P}<0,01)$, косою довжиною заду $-3,1$ см $(\mathrm{P}<0,001)$, масо-метричним коефіцієнтом - 10,6\% (P < 0,001). Це вказує про те, що дочки плідника Астрономера 2160438 є найважчими і найбільш високорослими.

Достовірна перевага дочок Кондона 397111 над групою напівсестер бугая Вірного 4975 встановлена одночасно за індексом високоногості $(2,4 \%, \mathrm{P}<0,001)$, що відповідає значенню у тварин молочного напряму продуктивності та компактності $(4,7 \%, \mathrm{P}<0,001)$, що притаманно тваринам 3 комбінованою продуктивністю, а також за індексом вираженості типу $(1,1 \%$, $\mathrm{P}<0,01)$. Це не узгоджується 3 традиційним уявлен- 
ням про молочний тип “довгих ліній” та свідчить про певний “голштинізований” тип будови тіла, спрямований на високу секрецію молока.

Аналіз молочної продуктивності та морфофункціональних властивостей вимені корів різного походження за батьком (табл. 2) засвідчив достовірну перевагу кращої групи напівсестер плідника Філдера 5573125 над гіршою групою дочок Вірного 4975 за усіма врахованими показниками, окрім жирно-, білковомолочності та швидкості молоковиведення $(\mathrm{P}<0,05-0,001)$.

\section{Таблиця 1}

Характеристика дочок різних бугаїв за масою тіла, промірами та індексами будови тіла $(\mathrm{M} \pm \mathrm{m})$

\begin{tabular}{|c|c|c|c|c|c|c|c|}
\hline $\begin{array}{c}\text { Показники, одиниці } \\
\text { виміру }\end{array}$ & $\begin{array}{c}\text { Вірний } \\
4975 \\
(\mathrm{n}=60)\end{array}$ & $\begin{array}{c}\text { Ділайт } \\
5422064 \\
(\mathrm{n}=84)\end{array}$ & $\begin{array}{c}\text { Клен } 5212 \\
(\mathrm{n}=109)\end{array}$ & $\begin{array}{l}\text { Кондон } \\
397111 \\
(\mathrm{n}=88)\end{array}$ & $\begin{array}{c}\text { Філдер } \\
5573125 \\
(\mathrm{n}=31)\end{array}$ & $\begin{array}{c}\text { Черчгіл Ет } \\
5568735 \\
(\mathrm{n}=65)\end{array}$ & $\begin{array}{c}\text { Астрономер } \\
2160438 \\
(\mathrm{n}=38)\end{array}$ \\
\hline Жива маса, кг & $497,8 \pm 7,52$ & $561,4 \pm 7,05$ & $528,2 \pm 6,12$ & $553,7 \pm 7,93$ & $538,4 \pm 12,19$ & $541,0 \pm 9,44$ & $570,7 \pm 8,50$ \\
\hline Проміри, см: & $1238+$ & $1293+054$ & & $12709+66$ & 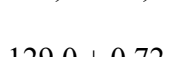 & & \\
\hline обхват грудей & $192,0 \pm 1,19$ & $202,0 \pm 0,95$ & $196,7 \pm 0,91$ & $201,0 \pm 1,15$ & $198,7 \pm 1,78$ & $198,5 \pm 1,36$ & $201,5 \pm 1,16$ \\
\hline $\begin{array}{l}\text { коса довжина тулуба } \\
\text { палицею }\end{array}$ & $146,8 \pm 0,86$ & $149,4 \pm 0,68$ & $147,9 \pm 0,55$ & $148,2 \pm 0,70$ & $147,6 \pm 1,06$ & $148,3 \pm 0,81$ & $151,0 \pm 1,05$ \\
\hline коса довжина заду & $47,5 \pm 0,26$ & $50,3 \pm 0,25$ & $48,5 \pm 0,22$ & $49,4 \pm 0,27$ & $49,5 \pm 0,45$ & $49,8 \pm 0,29$ & $50,6 \pm 0,30$ \\
\hline ширина в маклоках & $49,1 \pm 0,38$ & $51,2 \pm 0,27$ & $49,5 \pm 0,26$ & $50,0 \pm 0,34$ & $50,7 \pm 0,49$ & $50,5 \pm 0,32$ & $51,0 \pm 0,33$ \\
\hline $\begin{array}{l}\text { Індекси, \%: } \\
\text { високоногості }\end{array}$ & $45,6 \pm 0,40$ & $47,4 \pm 0,38$ & $45,6 \pm 0,34$ & $48,0 \pm 0,31$ & $47,1 \pm 0,50$ & $47,1 \pm 0,38$ & $45,9 \pm 0,44$ \\
\hline формату & $118,6 \pm 0,71$ & $115,7 \pm 0,61$ & $117,2 \pm 0,49$ & $114,3 \pm 0,56$ & $114,5 \pm 0,80$ & $\begin{array}{r}115,0 \pm 0,56 \\
11,1 \pm 0,50\end{array}$ & $115,5 \pm 0,80$ \\
\hline компактності & $131,0 \pm 0,86$ & $135,3 \pm 0,66$ & $133,1 \pm 0,64$ & $135,7 \pm 0,71$ & $134,8 \pm 1,24$ & $133,9 \pm 0,78$ & $133,7 \pm 0,95$ \\
\hline округлості ребер & $142,9 \pm 1,02$ & $148,9 \pm 0,94$ & $143,6 \pm 0,84$ & $149,4 \pm 0,86$ & $145,8 \pm 1,29$ & $145,6 \pm 0,95$ & $142,8 \pm 0,99$ \\
\hline формату таза & $94,2 \pm 0,70$ & $94,6 \pm 0,42$ & $95,4 \pm 0,44$ & $95,2 \pm 0,46$ & $92,9 \pm 0,56$ & $93,9 \pm 0,64$ & $95,8 \pm 0,52$ \\
\hline вираженості типу,\% & $24,4 \pm 0,25$ & $24,9 \pm 0,21$ & $24,7 \pm 0,21$ & $25,5 \pm 0,23$ & $24,7 \pm 0,41$ & $25,0 \pm 0,28$ & $25,0 \pm 0,28$ \\
\hline $\begin{array}{l}\text { масо-метричний } \\
\text { коефіцієнт, \% }\end{array}$ & $107,3 \pm 1,20$ & $116,5 \pm 1,09$ & $111,9 \pm 0,96$ & $115,2 \pm 1,20$ & $113,0 \pm 1,90$ & $113,3 \pm 1,48$ & $117,9 \pm 1,31$ \\
\hline $\begin{array}{l}\text { індекс ейрисомії- } \\
\text { лептосомії,\% }\end{array}$ & $286,2 \pm 1,73$ & $283,1 \pm 1,45$ & $286,3 \pm 1,48$ & $283,9 \pm 1,48$ & $285,5 \pm 3,10$ & $284,9 \pm 2,04$ & $284,8 \pm 1,71$ \\
\hline
\end{tabular}

\section{Таблиця 2}

Характеристика дочок різних бугаїв за молочною продуктивністю та морфо-функціональними властивостями вим'я $(\mathrm{M} \pm \mathrm{m})$

\begin{tabular}{|c|c|c|c|c|c|c|c|}
\hline $\begin{array}{c}\text { Показники, одиниці } \\
\text { виміру }\end{array}$ & $\begin{array}{c}\text { Вірний } \\
4975 \\
(\mathrm{n}=60) \\
\end{array}$ & $\begin{array}{c}\text { Ділайт } \\
5422064 \\
(\mathrm{n}=84)\end{array}$ & $\begin{array}{c}\text { Клен } 5212 \\
(\mathrm{n}=109)\end{array}$ & $\begin{array}{c}\text { Кондон } \\
397111 \\
(\mathrm{n}=88) \\
\end{array}$ & $\begin{array}{c}\text { Філдер } \\
5573125 \\
(\mathrm{n}=31)\end{array}$ & $\begin{array}{c}\text { Черчгіл Ет } \\
5568735 \\
(\mathrm{n}=65) \\
\end{array}$ & $\begin{array}{c}\text { Астрономер } \\
2160438 \\
(\mathrm{n}=38)\end{array}$ \\
\hline Надій за 305 дн, кг & $4329 \pm 123,2$ & $5360 \pm 110,5$ & $4379 \pm 80,1$ & $5257 \pm 103,3$ & $5715 \pm 198,0$ & $5100 \pm 130,4$ & $5091 \pm 144,6$ \\
\hline Жирномолочність, \% & & $3,98 \pm 0,048$ & $4,04 \pm 0,036$ & $53,91 \pm 0,034$ & $3,81 \pm 0,099$ & $4,02 \pm 0,055$ & 4,00 \\
\hline Молочний жир, кг & $173,6 \pm 5,68$ & $213,1 \pm 5,00$ & $176,2 \pm 3,36$ & $205,6 \pm 4,27$ & $219,5 \pm 10,35$ & $204,9 \pm 6,06$ & $202,9 \pm 5,92$ \\
\hline Білковомолочність, \% & $3,06 \pm 0,013$ & $3,09 \pm 0,017$ & & $3,08 \pm 0,012$ & $3,12 \pm 0,021$ & $3,15 \pm 0,014$ & $3,15 \pm 0,015$ \\
\hline Молочний білок, кг & $132,5 \pm 3,68$ & $166,4 \pm 3,42$ & $134,1 \pm 2$ & $162,0 \pm 3,21$ & $178,5 \pm 6,17$ & $160,8 \pm 4,30$ & 160,3 \\
\hline $\begin{array}{l}\text { Молочний жир + білок, } \\
\text { кг }\end{array}$ & $306,1 \pm 9,29$ & $379,5 \pm 8,15$ & $310,3 \pm 5,84$ & $367,6 \pm 7,25$ & $398,0 \pm 15,72$ & $365,7 \pm 10,12$ & $363,2 \pm 10,17$ \\
\hline Відносна молочність, кг & $875 \pm 27,9$ & $953 \pm 21,3$ & & & & & \\
\hline Обхв & $117,3=$ & $126,2 \pm$ & & 125,4 & 129 & 125 , & 127 , \\
\hline Дов & & & & & & & \\
\hline Ширина вим’я, см & $30,2 \pm 0,46$ & $33,0 \pm($ & $30,5 \pm$ & $31,8 \pm 0,30$ & $33,5 \pm 0,53$ & $32,0=$ & $32,6 \pm 0,52$ \\
\hline $\begin{array}{l}\text { Глибина задньої частки, } \\
\text { см }\end{array}$ & $26,8 \pm 0,47$ & $27,9 \pm 0,45$ & $26,8 \pm 0,33$ & $27,9 \pm 0,34$ & $28,1 \pm 0,54$ & $26,6 \pm 0,43$ & $26,1 \pm 0,57$ \\
\hline Умовний об’єм вим'я, л & $13,9 \pm 0,66$ & $17,2 \pm 0,47$ & $142+025$ & & $17,8 \pm 0,70$ & $16,1 \pm 0,48$ & $15,4 \pm 0,66$ \\
\hline Добовий надій, кг & $18,1 \pm 0,70$ & $22,3 \pm 0,55$ & $17,4 \pm 0,35$ & $20,8 \pm 0,53$ & $24,2 \pm 0,89$ & $21,9 \pm 0,63$ & $23,1 \pm 0,87$ \\
\hline $\begin{array}{l}\text { Швидкість молокови- } \\
\text { ведення, кг/хв }\end{array}$ & $1,34 \pm 0,070$ & $1,71 \pm 0,050$ & $1,42 \pm 0,034$ & $1,55 \pm 0,039$ & $1,86 \pm 0,112$ & $1,93 \pm 0,053$ & $1,94 \pm 0,059$ \\
\hline
\end{tabular}

Так, високодостовірна різниця за надоєм молока склала 1386 кг, сумарною продукцією молочного жиру і білка - 91,9 кг, обхватом, довжиною, шириною вимені та його умовним об'ємом - відповідно 12,6; 3,$9 ; 3,3$ см та 3,9 л, добовим надоєм - 6,1 кг молока $(\mathrm{P}<0,001)$.
Найвищою жирномолочністю (4,04\%) відзначалися напівсестри плідника Клена 5212 за достовірної переваги над дочками Філдера 5573125 в 0,23\% $(\mathrm{P}<0,05)$. Щодо білковомолочності, то кращими показниками (3,15\%) відзначалися дочки бугаїв Черчгіла Ет 5568735 та Астрономера 2160438 за високодосто- 
вірної переваги над гіршими за цим показником дочками Вірного 4975 (Р $<0,001)$.

Швидкість молоковиведення коливалася від 1,34 кг/хв у напівсестер плідника Вірного 4975 до 1,94 кг/хв - Астрономера 2160438 (різниця - 0,6 кг/хв, $\mathrm{P}<0,001)$.

Дочки різних бугаїв відрізнялися за відтворювальною здатністю (табл. 3). Найменшим віком першого отелення відзначалися дочки Вірного 4975, найбільшим - Черчгіла Ет 5568735 за високодостовірної різниці (4,9 міс., Р < 0,001). Щодо тривалості сервіс- та міжотельного періодів, то у всіх груп напівсестер за батьком вони перевищували оптимальні значення (сервіс-період 60-80 днів, міжотельний 365-385).
Найменша тривалість зазначених періодів відмічена у дочок Вірного 4975, які мали найвищий коефіцієнт відтворювальної здатності проти найдовшої їх тривалості у дочок Філдера 5573125 за найменшого коефіцієнта відтворювальної здатності $(\mathrm{P}<0,05-0,01)$. Інші дочки бугаїв суттєво не відрізнялися за показниками відтворювальної здатності. Зазначений коефіцієнт коливався у них в межах 0,85-0,88 та відхилявся від норми в 1 .

У результаті аналізу даних таблиць 2 та 3 встановлено, що тварини 3 найвищими показниками молочної продуктивності характеризувалися найгіршою відтворювальною здатністю.

\section{Таблиця 3}

Характеристика дочок різних бугаїв за відтворювальною здатністю $(\mathrm{M} \pm \mathrm{m})$

\begin{tabular}{|c|c|c|c|c|c|c|c|}
\hline $\begin{array}{c}\text { Показники, одиниці } \\
\text { виміру }\end{array}$ & $\begin{array}{c}\text { Вірний } \\
4975 \\
(\mathrm{n}=60) \\
\end{array}$ & $\begin{array}{c}\text { Ділайт } \\
5422064 \\
(\mathrm{n}=84) \\
\end{array}$ & $\begin{array}{c}\text { Клен } 5212 \\
(\mathrm{n}=109)\end{array}$ & $\begin{array}{c}\text { Кондон } \\
397111 \\
(\mathrm{n}=88) \\
\end{array}$ & $\begin{array}{c}\text { Філдер } \\
5573125 \\
(\mathrm{n}=31) \\
\end{array}$ & $\begin{array}{c}\text { Черчгіл Ет } \\
5568735 \\
(\mathrm{n}=65) \\
\end{array}$ & $\begin{array}{c}\text { Астрономер } \\
2160438 \\
(\mathrm{n}=38) \\
\end{array}$ \\
\hline $\begin{array}{l}\text { Вік І-го отелення, міс. } \\
\text { Тривалість, днів: }\end{array}$ & $29,4 \pm 0,37$ & $32,5 \pm 0,47$ & $30,4 \pm 0,39$ & $30,0 \pm 0,57$ & $29,6 \pm 1,04$ & $34,3 \pm 0,99$ & $32,0 \pm 0,81$ \\
\hline сервіс-періоду & $119,0 \pm 10,61$ & $170,0 \pm 12,54$ & $151,3 \pm$ & $155,5 \pm 10,51$ & $179,8 \pm 21,77$ & $164,8 \pm 12,43$ & $149,3=$ \\
\hline міжотельного періоду & $400,6 \pm 10,78$ & $450,7 \pm 12,51$ & & $437,6 \pm 10,51$ & $461,6 \pm 21,69$ & $446,3 \pm 12,42$ & $429,2 \pm 10,44$ \\
\hline $\begin{array}{l}\text { Коефіцієнт відтворю- } \\
\text { вальної здатності }\end{array}$ & $0,94 \pm 0,021$ & $0,85 \pm 0,021$ & $0,88 \pm 0,017$ & $0,87 \pm 0,018$ & $0,83 \pm 0,033$ & $0,85 \pm 0,021$ & $0,87 \pm 0,019$ \\
\hline
\end{tabular}

Традиційним для вітчизняної селекційної практики і нерідко результативним способом селекційного поліпшення стад молочної худоби вважається використання методу розведення за лініями (Bazyshyna, 2017).

Найчисельнішими лініями молочного стада даного племзаводу були лінії Старбака (317 гол.), Чіфа (161 гол.), Валіанта (68 гол.), Сейлінг Трайджун Рокіта (63 гол.) та Віс Бурке Айдіала (25 гол.), за показниками нащадків яких і проведено порівняння господарськи корисних ознак. Міжгрупова диференціація маси тіла та промірів тіла корів різних ліній була значною (табл. 4).

\section{Таблиця 4}

Характеристика корів різних ліній за масою тіла, промірами та індексами будови тіла $(\mathrm{M} \pm \mathrm{m})$

\begin{tabular}{|c|c|c|c|c|c|}
\hline Показники, одиниці виміру & $\begin{array}{c}\text { Валіанта } \\
(\mathrm{n}=68)\end{array}$ & $\begin{array}{c}\text { Вic } \\
\text { Бурке Айдіала } \\
(\mathrm{n}=25)\end{array}$ & $\begin{array}{l}\text { Старбака } \\
(\mathrm{n}=317)\end{array}$ & $\begin{array}{c}\text { Сейлінг } \\
\text { Трайджун Рокіта } \\
(\mathrm{n}=63)\end{array}$ & $\begin{array}{c}\text { Чiфа } \\
(\mathrm{n}=161)\end{array}$ \\
\hline Маса тіла, кг & $572,7 \pm 6,86$ & $525,5 \pm 11,25$ & $553,4 \pm 3,91$ & $501,3 \pm 7,42$ & $550,4 \pm 5,80$ \\
\hline Проміри, см: & & & & & \\
\hline висота в холці & $131,6 \pm 0,65$ & $129,6 \pm 0,88$ & $129,5 \pm 0,29$ & $124,5 \pm 0,61$ & $128,5 \pm 0,48$ \\
\hline обхват грудей & $202,1 \pm 0,99$ & $198,2 \pm 1,96$ & $200,5 \pm 0,55$ & $192,4 \pm 1,18$ & $199,8 \pm 0,83$ \\
\hline коса довжина тулуба палицею & $151,2 \pm 0,70$ & $148,0 \pm 0,90$ & $148,8 \pm 0,36$ & $147,1 \pm 0,84$ & $149,4 \pm 0,48$ \\
\hline коса довжина заду & $51,0 \pm 0,31$ & $47,6 \pm 0,54$ & $49,9 \pm 0,13$ & $47,6 \pm 0,26$ & $49,4 \pm 0,20$ \\
\hline ширина в маклоках & $51,7 \pm 0,25$ & $49,8 \pm 0,50$ & $50,7 \pm 0,15$ & $49,2 \pm 0,37$ & $50,3 \pm 0,22$ \\
\hline Індекси, \%: . . & & & & & \\
\hline високоногості & $46,0 \pm 0,38$ & $45,8 \pm 0,48$ & $47,1 \pm 0,18$ & $45,9 \pm 0,38$ & $46,0 \pm 0,29$ \\
\hline формату & $115,0 \pm 0,59$ & $114,3 \pm 0,91$ & $115,1 \pm 0,29$ & $118,2 \pm 0,70$ & $116,4 \pm 0,39$ \\
\hline компактності & $133,8 \pm 0,69$ & $134,0 \pm 1,41$ & $134,8 \pm 0,36$ & $131,0 \pm 0,83$ & $133,8 \pm 0,51$ \\
\hline округлості ребер & $142,6 \pm 0,87$ & $141,4 \pm 1,35$ & $146,9 \pm 0,46$ & $143,2 \pm 0,99$ & $144,6 \pm 0,81$ \\
\hline формату таза & $94,4 \pm 0,39$ & $96,2 \pm 0,94$ & $94,6 \pm 0,24$ & $94,1 \pm 0,67$ & $95,4 \pm 0,32$ \\
\hline вираженості типу,\% & $24,9 \pm 0,23$ & $26,2 \pm 0,28$ & $25,1 \pm 0,12$ & $24,4 \pm 0,24$ & $24,9 \pm 0,16$ \\
\hline масо-метричний коефіцієнт, \% & $117,9 \pm 1,03$ & $110,3 \pm 1,77$ & $115,2 \pm 0,60$ & $107,8 \pm 1,17$ & $114,8 \pm 0,87$ \\
\hline індекс ейрисомії-лептосомії,\% & $284,1 \pm 1,42$ & $280,4 \pm 2,34$ & $284,1 \pm 0,79$ & $286,7 \pm 1,63$ & $285,3 \pm 1,09$ \\
\hline
\end{tabular}

Так, корови лінії Валіанта (найвищі показники маси тіла та промірів тіла) 3 високою достовірністю переважали тварин лінії Сейлінг Трайджун Рокіта (мінімальні значення серед груп за лініями) за масою тіла на 71,4 кг та за усіма врахованими промірами тіла (за висотою в холці - на 7,1 см; обхватом грудей 9,7 см; косою довжиною тулуба - 4,1 см; косою довжиною заду - 3,4 см; шириною в маклоках - 2,5 см, $\mathrm{P}<0,001)$, а також вони мали найвищий масометричний коефіцієнт. 
Щодо індексів будови тіла, то найвищими індексами високоногості, компактності та округлості ребер характеризувалися корови лінії Старбака, найвищими індексами формату таза та вираженості типу - корови лінії Віс Бурке Айдіала, формату та індекса ейрисоміїлептосомії - корови лінії Сейлінг Трайджун Рокіта за достовірної переваги над мінімальними значення перерахованих індексів.

Значний рівень диференціації виявлено при порівнянні групових середніх корів різних ліній за молочною продуктивністю та морфо-функціональними властивостями вимені (табл. 5).

\section{Таблиця 5}

Характеристика корів різних ліній за молочною продуктивністю та морфо-функціональними властивостями вим'я $(\mathrm{M} \pm \mathrm{m})$

\begin{tabular}{lccccc}
\hline \multicolumn{1}{c}{ Показники, одиниці виміру } & $\begin{array}{c}\text { Валіанта } \\
(\mathrm{n}=68)\end{array}$ & $\begin{array}{c}\text { Вурке Айдіала } \\
(\mathrm{n}=25)\end{array}$ & $\begin{array}{c}\text { Старбака } \\
(\mathrm{n}=317)\end{array}$ & $\begin{array}{c}\text { Сейлінг } \\
\text { Трайджун } \\
\text { Рокіта }(\mathrm{n}=63)\end{array}$ & $\begin{array}{c}\text { Чіфа } \\
(\mathrm{n}=161)\end{array}$ \\
\hline Надій за 305 дн, кг & $5320 \pm 125,8$ & $5584 \pm 213,3$ & $5262 \pm 57,0$ & $4361 \pm 120,6$ & $4791 \pm 85,5$ \\
Жирномолочність, \% & $3,98 \pm 0,037$ & $3,96 \pm 0,073$ & $3,96 \pm 0,023$ & $3,97 \pm 0,042$ & $4,03 \pm 0,031$ \\
Молочний жир, кг & $211,6 \pm 5,14$ & $218,0 \pm 6,99$ & $208,3 \pm 2,53$ & $173,9 \pm 5,52$ & $192,5 \pm 3,53$ \\
Білковомолочність, \% & $3,08 \pm 0,012$ & $3,10 \pm 0,030$ & $3,11 \pm 0,007$ & $3,07 \pm 0,014$ & $3,07 \pm 0,009$ \\
Молочний білок, кг & $163,6 \pm 3,81$ & $185,3 \pm 10,97$ & $163,9 \pm 1,80$ & $133,9 \pm 3,71$ & $147,0 \pm 2,64$ \\
Молочний жир+білок, кг & $375,2 \pm 8,59$ & $403,3 \pm 13,08$ & $372,2 \pm 4,19$ & $307,8 \pm 9,14$ & $339,5 \pm 6,08$ \\
Відносна молочність, кг & $927 \pm 21,8$ & $1049 \pm 35,6$ & $947 \pm 11,4$ & $870 \pm 26,5$ & $877 \pm 13,8$ \\
Обхват вим'я, см & $128,3 \pm 1,15$ & $132,5 \pm 2,58$ & $126,3 \pm 0,57$ & $117,4 \pm 1,69$ & $123,0 \pm 0,90$ \\
Довжина вим'я, см & $41,3 \pm 0,42$ & $45,1 \pm 0,77$ & $40,9 \pm 0,25$ & $38,2 \pm 0,77$ & $39,7 \pm 0,38$ \\
Ширина вим’я, см & $32,1 \pm 0,37$ & $33,4 \pm 0,65$ & $32,5 \pm 0,17$ & $30,2 \pm 0,45$ & $31,0 \pm 0,24$ \\
Глибина задньої частки,см & $26,8 \pm 0,49$ & $27,8 \pm 0,72$ & $27,3 \pm 0,20$ & $27,0 \pm 0,45$ & $26,8 \pm 0,27$ \\
Умовний об'єм вим’я, л & $16,1 \pm 0,48$ & $18,9 \pm 0,80$ & $16,4 \pm 0,23$ & $14,1 \pm 0,65$ & $14,9 \pm 0,31$ \\
Добовий надій, кг & $22,3 \pm 0,61$ & $22,6 \pm 0,86$ & $22,0 \pm 0,29$ & $18,1 \pm 0,68$ & $19,4 \pm 0,40$ \\
Швидкість молоковиведення, кг/хв & $1,74 \pm 0,046$ & $1,43 \pm 0,096$ & $1,75 \pm 0,026$ & $1,36 \pm 0,053$ & $1,57 \pm 0,032$ \\
\hline
\end{tabular}

Так, за надоєм за 305 днів лактації високодостовірну перевагу над тваринами лінії Сейлінг Трайджун Рокіта мали корови лінії Віс Бурке Айдіала (1223 кг, $\mathrm{P}<0,001)$. Високодостовірна перевага на їх користь встановлена також за молочним жиром (44,1 кг), молочним білком (51,4 кг), їх сумарною кількістю (95,5 кг), відносною молочністю (179 кг), а також за усіма врахованими параметрами вимені $(\mathrm{P}<0,001)$, окрім швидкості молоковиведення.

Достовірної переваги за жирномолочністю та білковомолочністю між коровами різних ліній не встано- влено, в тому числі між мінімальними та максимальними значеннями.

Найнижчими показниками відтворення характеризувалися корови лінії Старбака (табл. 6). Вони мали триваліший сервіс- та міжотельний періоди (відповідно на 44,6 та 43,8 дн., Р < 0,001) та гірший коефіцієнт відтворювальної здатності (на $0,08, \mathrm{P}<0,001$ ) за високодостовірної різниці з кращими показниками корів лінії Сейлінг Трайджун Рокіта.

\section{Таблиця 6}

Характеристика корів різних ліній за відтворювальною здатністю $(\mathrm{M} \pm \mathrm{m})$

\begin{tabular}{lccccc}
\hline \multicolumn{1}{c}{ Показники, одиниці виміру } & $\begin{array}{c}\text { Валіанта } \\
(\mathrm{n}=68)\end{array}$ & $\begin{array}{c}\text { Бурке Айдіала } \\
(\mathrm{n}=25)\end{array}$ & $\begin{array}{c}\text { Старбака } \\
(\mathrm{n}=317)\end{array}$ & $\begin{array}{c}\text { Сейлінг } \\
\text { Трай Рокіта } \\
(\mathrm{n}=63)\end{array}$ & $\begin{array}{c}\text { Чіфа } \\
(\mathrm{n}=161)\end{array}$ \\
\hline Вік І-го отелення, міс. & $33,3 \pm 0,75$ & $29,2 \pm 0,57$ & $32,1 \pm 0,34$ & $29,6 \pm 0,50$ & $31,2 \pm 0,35$ \\
Тривалість, днів: & & & & & \\
сервіс-періоду & $137,0 \pm 10,96$ & $136,5 \pm 22,85$ & $162,4 \pm 5,75$ & $117,8 \pm 10,26$ & $151,0 \pm 7,65$ \\
міжотельного періоду & $417,2 \pm 10,99$ & $420,2 \pm 22,99$ & $443,5 \pm 5,73$ & $399,7 \pm 10,41$ & $431,8 \pm 7,73$ \\
Коефіціснт відтворювальної здатності & $0,90 \pm 0,019$ & $0,91 \pm 0,039$ & $0,86 \pm 0,010$ & $0,94 \pm 0,020$ & $0,88 \pm 0,014$ \\
\hline
\end{tabular}

Отже, міжгрупова диференціація корів різної лінійної належності, як і напівсестер за батьком, за досліджуваними господарськи корисними ознаками у багатьох випадках виявилась значною і високодостовірною.

Однофакторним дисперсійним аналізом встановлено, що суттєвіший вплив на господарськи корисні ознаки корів справляє походження за батьком. Частка впливу батька на мінливість окремих промірів коливалася від 2,89 до $15,61 \%$, індексів будови тіла - від 0,71 до 9,88\%, показників молочної продуктивності - від 2,50 до 20,79\%, морфо-функціональних властивостей вим'я - від 3,44 до 21,92\%, показників відтворювальної здатності - від 2,84 до 9,34\% в переважній більшості за достовірних значень.

Вплив належності до лінії був меншим. На мінливість окремих промірів він складав від 2,44 до 12,70\%, індексів будови тіла - від 0,74 до 5,96\%, показників молочної продуктивності - від 0,63 до 11,15\%, морфофункціональних властивостей вимені - від 0,54 до 8,89\%, показників відтворювальної здатності - від 
2,31 до 3,54\% в переважній більшості за достовірних значень.

Таким чином, фенотипова мінливість господарськи корисних ознак корів української чорно-рябої молочної породи певною мірою зумовлюється впливом генетичних факторів, таких як походження за батьком та лінійна належність.

\section{Висновки}

Міжгрупова диференціація корів різної лінійної належності та напівсестер за батьком за досліджуваними господарськи корисними ознаками у багатьох випадках виявилась значною і високодостовірною.

Однофакторним дисперсійним аналізом встановлено, що суттєвіший вплив на господарськи корисні ознаки корів справляє походження за батьком, що зумовлює 0,71-21,92\% загальної фенотипової мінливості враховуваних ознак, тимчасом як а належність до лінії-0,54-12,70\%.

Перспективи подальших досліджень. У подальшому буде вивчено вплив походженням за батьком та лінійної належності корів української чорно-рябої молочної породи на параметри їх довічної продуктивності.

\section{References}

Bazyshyna, I.V. (2017). Formuvannya hospodars'ky korysnykh oznak molochnoyi khudoby zalezhno vid pokhodzhennya za bat'kom, liniyi ta sporidnenoyi hrupy. Rozvedennya i henetyka tvaryn, 53, 69-78. http://nbuv.gov.ua/UJRN/rgt_2017_53_11 (in Ukrainian).

Dmitriev, N.G., Loginov, Zh.G., \& Prohorenko, P.N. (1989). Metodicheskie rekomendacii po ispol'zovaniju molodyh golshtinskih bykov-synovej liderov porody. Leningrad (in Russian).
Rusnak, P.Y., \& Shcherbatyy, Z.Ye. (1999). Otsinka henotypu buhayiv-plidnykiv. Rozvedennya i henetyka tvaryn, 31-32, 208-209 (in Ukrainian).

Karacaören, B., Jaffrézic, F., \& Kadarmideen, H.N. (2006). Genetic parameters for functional traits in dairy cattle from daily random regression models. Journal of Dairy Science, 89(2), 791-798. https://www.ncbi.nlm.nih.gov/pubmed/16428647.

Vandenplas, J., Bastin, C., Gengler, N., \& Mulder, H.A. (2013). Genetic variance in microenvironmental sensitivity for milk and milk quality in Walloon Holstein cattle. Journal of Dairy Science, 96(9), 5977-5990. https://www.ncbi.nlm.nih.gov/pubmed/23871372.

Shcherbatyi, Z.Ye., \& Bodnar, P.V. (2015). Molochna produktyvnist' koriv ukrayins'koyi chorno-ryaboyi molochnoyi porody dochok riznykh holshtyns'kykh buhayiv. Nauk. visn. LNUVMBT imeni S.Z. Gzhyts'koho, 17, 3(63), 347-354. http://nbuv.gov.ua/UJRN/nvlnu_2015_17_3_67 (in Ukrainian).

Iliashenko, H.D., \& Polupan, Yu.P. (2009). Vplyv henetychnykh ta paratypnykh chynnykiv na molochnu produktyvnist koriv ukrainskoi chervonoi ta chornoriaboi molochnykh porid. Visnyk stepu, 6, 129-136 (in Ukrainian).

Stavets'ka, R., \& Rudyk, I. (2011). Molochna produktyvnist' ukrayins'koyi chorno-ryaboyi khudoby: selektsiyni osoblyvosti. Tvarynnytstvo Ukrayiny, 11, 1822 (in Ukrainian).

Merkur'eva, E.K. (1970). Biometriya v selektsii i genetike sel'skokhozyaystvennykh zhivotnykh. Moscow: Kolos (in Russian).

Plohinskij, N.A. (1969). Rukovodstvo po biometrii dlya zootekhnikov. Moscow: Kolos (in Russian).

Plohinskij, N.A. (1970). Biometrija. M.: Izd-vo MGU (in Russian). 